\title{
Post-fire soil hydrology, water erosion and restoration strategies in Andosols: a review of evidence from the Canary Islands (Spain)
}

\author{
Jonay Neris ${ }^{(1-2)}$, Juan C \\ Santamarta ${ }^{(3)}$, Stefan H Doerr ${ }^{(1)}$, \\ Francisco Prieto ${ }^{(4)}$, Juan \\ Agulló-Pérez ${ }^{(5)}$, Paloma García- \\ Villegas ${ }^{(5)}$
}

\begin{abstract}
Andosols are the most characteristic soils of volcanic regions such as the forested, fire-prone, hillslopes of the mountainous Canary Islands (Spain). Due to their volcanic nature, these soils have traditionally been considered highly resistant to water erosion processes in undisturbed conditions, but are also highly susceptible to environmental disturbances. In addition, volcanic terrains often underlie heavily-populated, steep areas where torrential rains are frequent, increasing the threat to the population and infrastructures downslope. Numerous hydrological and erosional catastrophic events in disturbed Andosols in the Canary Islands and worldwide, leading to major losses to lives and properties, have been historically and recently reported. The impact of environmental alterations such as land use change on hydrological and erosional response of Andosols has been widely studied in the Canary Islands and worldwide. However, the effect on this soil type of wildfires, generally considered one of the main geomorphological agents, and historically connected to the forested fire-prone Andosols of the islands, has had scant attention to date. This review seeks to redress this knowledge gap by: (i) evaluating the factors affecting the susceptibility of Andosols to catastrophic hydrological and erosional events; (ii) summarizing the published studies on the impact of fire and the post-fire response of this soil type and the specific restoration measures developed to date; and (iii) identifying research gaps and suggesting new lines of investigation in order to reduce the hydrological and erosional risks in these particular terrains.
\end{abstract}

Keywords: Volcanic Ash Soils, Wildfires, Catastrophic Events, Disaster Risk Reduction, Erosion Mitigation, Post-fire Restoration particularly around the Pacific rim and Pacific islands, the African Rift Valley, Atlantic islands of Macaronesia and areas of Italy, France, Germany and Iceland (IUSS Working Group 2014 - Fig. 1a). Their volcanic nature provides high fertility to these soils and an increased resistance to erosion processes (Nanzyo et al. 1993, Perrin et al. 2001) due to their mineralogy, containing
(1) Swansea University, Dept. of Geography, College of Science, Swansea SA2 8PP, West Glamorgan (UK); (2) Dpto. Biología Animal y Edafología y Geología, Facultad de Biología, Universidad de La Laguna, Av. Astrofísico Fco. Sánchez s/n, 38071 La Laguna, Tenerife (Spain); (3) Dpto. Ingeniería de la Producción y Economía Agraria, Universidad de La Laguna, Carretera General de Geneto 2, 38071 La Laguna, Tenerife (Spain); (4) Servicio de Medio Ambiente, Seguridad y Emergencias del Cabildo Insular de La Palma, Av. de los Indianos 20, 38700 Santa Cruz de La Palma (Spain); (5) Servicio Técnico de Planificación y Proyectos Forestales del Cabildo Insular de Tenerife, C/ Las Macetas sn, Pabellón Santiago Martín, 38108 La Laguna (Spain)

@ Jonay Neris (jneris@ull.edu.es)

Received: Feb 17, 2015 - Accepted: Nov 30, 2015

Citation: Neris J, Santamarta JC, Doerr SH, Prieto F, Agulló-Pérez J, García-Villegas P (2016). Post-fire soil hydrology, water erosion and restoration strategies in Andosols: a review of evidence from the Canary Islands (Spain). iForest 9: 583-59210. - doi: 10.3832/ifor1605-008 [online 2016-03-17]

Communicated by: Davide Ascoli non-crystalline minerals, high organic matter content (SOM), and the reciprocal stabilization of these fractions (Al-, Fe-humus complexes - Warkentin \& Maeda 1980, Hoyos \& Comerford 2005). These properties contribute to the generally reported high infiltration rates, and low susceptibility to particle detachment and erosion processes of undisturbed Andosols (Nanzyo et al. 1993, Jiménez et al. 2006). Additionally, volcanic soils typically show high fertility and, consequently, are often associated with high population densities. However, Andosols' properties and functions are highly susceptible to changes in land use (Buytaert et al. 2002, Hoyos \& Comerford 2005, Rahman et al. 2008) and vegetation (Jiménez et al. 2006, Neris et al. 2012).

Along with disturbances related to land use and vegetation change, wildfires can lead to severe alterations of the hydrological and erosional responses of soils, sometimes with catastrophic consequences (Shakesby \& Doerr 2006). Although few studies have evaluated fire impacts on Andosols properties, it has been demonstrated that temperature increases and intense drying processes due to deforestation can have a detrimental effect on their hydrological and erosional properties (Buytaert et al. 2002, Woignier et al. 2008, Dorner et al. 2009). In addition to these sci- 


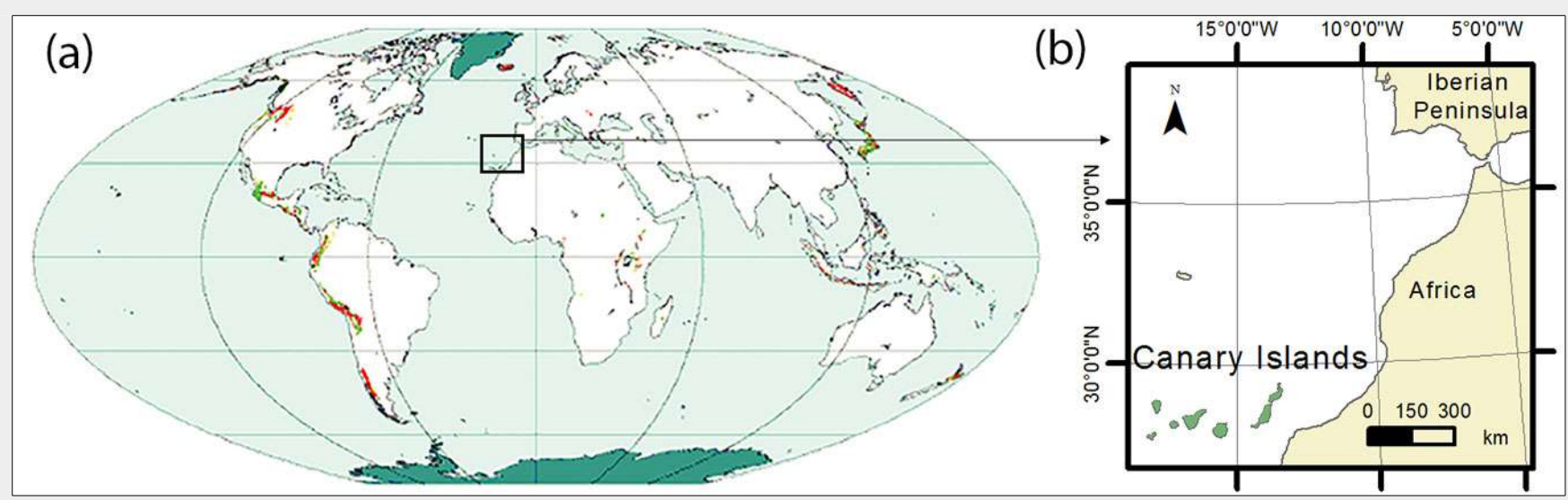

Fig. 1 - (a) Distribution of Andosols as: dominant soils (red), associated with other soil types (light green) and as inclusions (yellow). Miscellaneous lands in turquoise (inland waterbodies, glaciers and no data). Source: modified from Driessen et al. (2001). (b) Location of the Canary Islands.

entific findings, the history of the Canary Islands, a volcanic archipelago located between $27^{\circ} 37^{\prime}$ and $29^{\circ} 25^{\prime} \mathrm{N}$ and $13^{\circ} 20^{\prime}$ and $18^{\circ} 10^{\prime} \mathrm{W}$ (Fig. 1), includes numerous catastrophic hydrological and erosional events recorded in written records dating back from the $16^{\text {th }}$ century to the present (Barreto 1979, Redacción 1990, Brito I, personal communication). The most recent catastrophic event took place in 2009 after a forest fire (4000 ha of pine forest burned) and a series of rainstorms $(550 \mathrm{~mm}$ in 12 days) that triggered several debris flows, which even reached the coastline from an initial altitude of $800 \mathrm{~m}$. They affected crops, housing, communication routes, water and electricity supply and other infrastructures (Fig. 2). This archipelago is particularly susceptible to the occurrence, and hence ideal for the study of, fire-induced catastrophic hydrological and erosional events due to its morphology, climate, soils, vegetation and population density. Its islands are characterized by steep slopes around volcanic cones (some 35\% of the island of Tenerife exceeds $30 \%$ in slope) with Andosols frequently located on densely forested northern hillslopes. The an nual precipitation exceeds $1000 \mathrm{~mm}$ in some areas and over $80 \%$ takes place in autumn and winter. Atlantic storms characterized by torrential rains exceeding intensities of $100 \mathrm{~mm}$ day $^{-1}$ and $300 \mathrm{~mm} \mathrm{day}^{-1}$, with return periods of 5 and 30 years res pectively, are frequent in these seasons (Marzol Jaén 1988). Additionally, most islands are densely populated, with figures almost quintupling the European average (e.g., 542 people $\mathrm{km}^{-2}$ in Gran Canaria vs. 112 people $\mathrm{km}^{-2}$ in the European Union), which increases dramatically the probability of fire-induced catastrophic events. Forest fires are frequent in Canary Islands mainly due to: (i) the high human pressure on the wildland-urban interface; (ii) the large forested area, which covers $50 \%$ of some of the western islands; (iii) the botanical composition of these forests, which usually include highly flammable plants such as Pinus, Erica, Adenocarpus or Chamaecytisus; and (iv) the alternation of wet and dry seasons, which promote fuel load increase and facilitate the occurrence of wildfires, respectively (Notario del Pino 2009). Several large and recurrent wildfires have occurred in the Canary Islands over the last 45 years (Fig. 3). The average number of wildfires per year is 70 and the average area affected is 2560 ha per year in the period 19682013 (Instituto Canario de Estadística 2015).

Historical and recent catastrophic events triggered by torrential rains after forest fires in Andosols of the Canary Islands and worldwide highlight the post-fire geomorphological instability of Andosols. Therefore, it is essential to widen the knowledge on preventing the fire occurrence in this terrain type but, as fire is a recurrent environmental agent, also on predicting and mitigating the increased risk to the population downslope during the post-fire period. This review seeks to fill this research gap by summarizing current research on fire effects on Andosols' properties and functions and innovative restoration strategies developed in the post-fire period, as well as identifying new lines of research on the fire-induced impacts on the hydrological and erosional response of Andosols, with a special focus on the contributions from the Canary Islands (Spain).

\section{The impact of fire on Andosols' properties}

Fire affects several properties of Andosols that are relevant to their hydrological and erosional responses. Andosols have shown a substantial decrease of aggregate stability (AS) after wildfire both in Canary Islands (Neris et al. 2013a) and South America (Morales et al. 2013), which can reduce their infiltration capacity and enhance erosional processes. Data published by the above authors shows that AS figures decreased more than $15 \%$ in half of the fireaffected Andosols studied, whereas 30\% of those Andosols showed a decrease of AS exceeding $20 \%$ (Fig. 4b). In contrast, the decrease in AS after fire reported for other soil types rarely exceeded 15\% (Marcos et al. 2007, O'Dea 2007, Campo et al. 2008, Terefe et al. 2008, Are et al. 2009, Varela et al. 2010, Mataix-Solera et al. 2011, Badia-Villas et al. 2014 - Fig. 4b). According to Mataix-Solera et al. (2011) this is the typical response of soils such as Andosols, whose main binding agent is SOM (Candan \& Broquen 2009). As reported by several authors (De La Rosa et al. 2013, Morales et al. 2013, Neris et al. 2013a, 2014), Andosols' SOM can be severely reduced and its chemical composition altered by fire. According to the aforementioned authors, fire-induced SOM reduction ranges from 20 to $4 \mathrm{~g} 100$ $\mathrm{g}^{-1}$ and $>50 \%$ of the fire-affected soils evaluated showed a decrease in excess of $10 \mathrm{~g}$ $100 \mathrm{~g}^{-1}$ (Fig. 4a). Contrastingly, the reduction of SOM in non-volcanic soils rarely

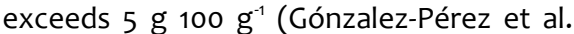
2004, Varela et al. 2010, Certini et al. 2011 Fig. 4a). Additionally, several authors have reported a significant decrease in AS and the alteration of soil porosity of volcanic soils under severe drying processes (Buytaert et al. 2002, Woignier et al. 2008, Dorner et al. 2010). The combined impact of fire on both SOM and soil mineralogy could explain the considerably high reduction of AS exhibited by Andosols.

Increases in bulk density (BD) could be expected for soils after fire due to the reduction of aggregate stability and the decrease of the protection of the litter cover against raindrop impact (Giovannini \& Lucchesi 1997). However, fire-affected Andosols have showed considerably low values of $\mathrm{BD}$ after fire, enhancing both wind and water erosion processes. Studies carried out in the Canary Islands (Neris et al. 2013a, 2014) and South-America (Morales et al. 2013) reported figures reaching $0.5 \mathrm{Mg} \mathrm{m}^{-3}$. This response can be attributed to irreversible changes in the soil structure due to severe drying processes, as previously observed in agricultural Andosols from the Canary Islands affected by intense drying periods (Hernández-Moreno et al. 2007). Neris et al. (2014) hypothesized that, since wildfires lead to severe drying processes similar to those caused by land use change, 
a comparable response of bulk density can be expected. However, further research is needed to understand this response.

Fire-induced impacts on both aggregate stability and bulk density of Andosols affect their pore size distribution. According to Neris et al. (2013a), water retention at 33 $\mathrm{kPa}$ can show a considerable increase after the fire in accordance with the decrease of bulk density, but in contrast to the observed decrease in aggregate stability. Although an increase in water retention at 33
$\mathrm{kPa}$ of tension has been reported widely for different soil types, the reported figures for burned Andosols (up to $75 \%$ of water retention at $33 \mathrm{kPa}$ after the fire) largely exceeded those reported for nonvolcanic soils (Are et al. 2009, Stoof et al. 2010). This can enhance infiltration and reduce both runoff and erosion. According to Stoof et al. (2010) and Neris et al. (2014), this response can be attributed to the incorporation of partially combusted char, which generally shows a higher amount of large pores compared to the soil itself (Cerdà \& Doerr 2008). However, the effect of fire on water retention at $1500 \mathrm{kPa}$ is generally less pronounced than at lower tensions. This is probably due to the limited impact of fire on soil texture, main responsible for water retention at this tension (Stoof et al. 2010, Neris et al. 2013a, 2014). Most authors suggest that fire induces or enhances soil water repellency (Imeson et al. 1992, Letey 2001, Doerr et al. 2006). However, the findings by Jordán et al.

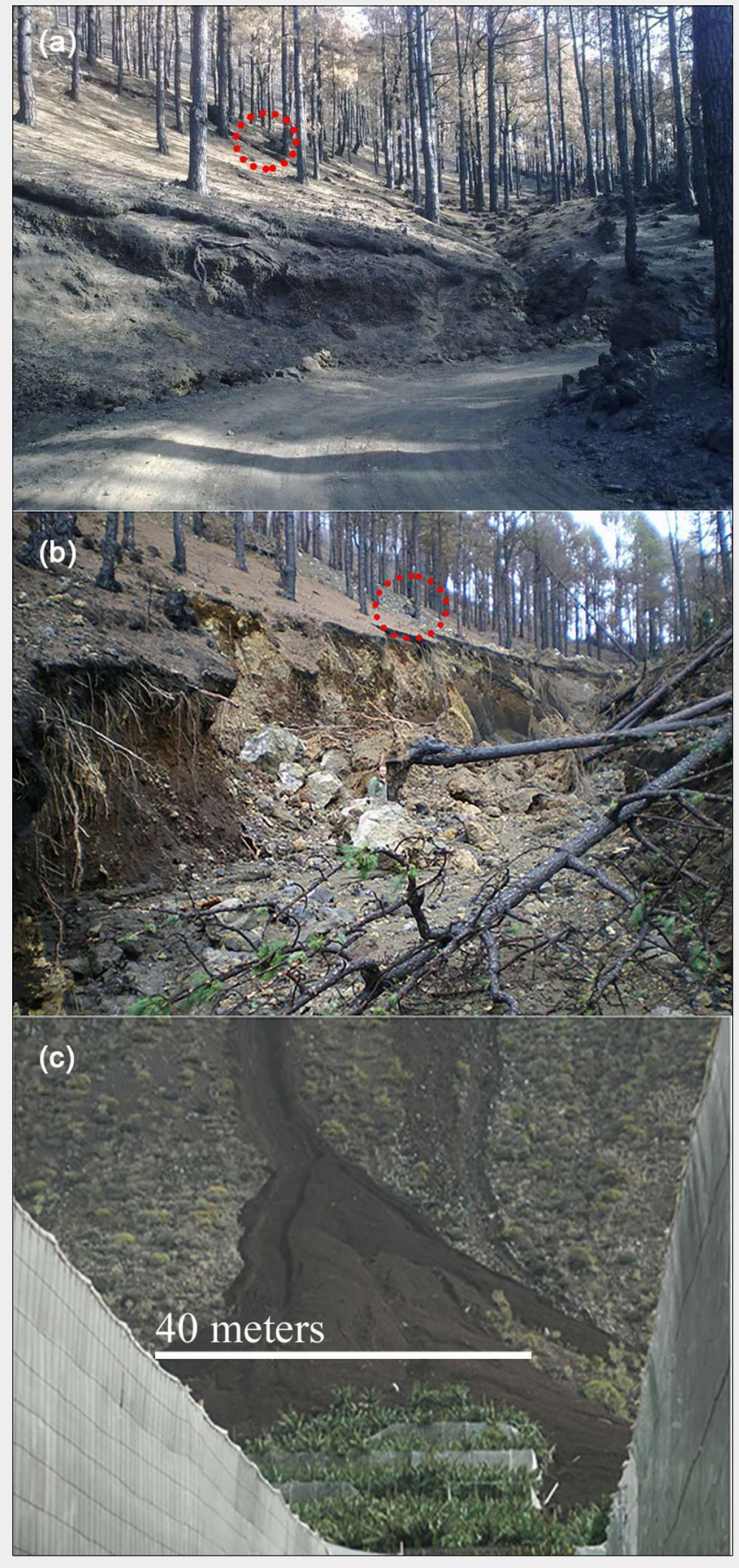

Fig. 2 - Landslides after the forest fire in La Palma (2009). Forest road before (a) and after (b) the torrential rains and subsequent landslides in 2009. Sediment deposition after the landslide affecting banana crops near the southern coastline of La Palma (c).
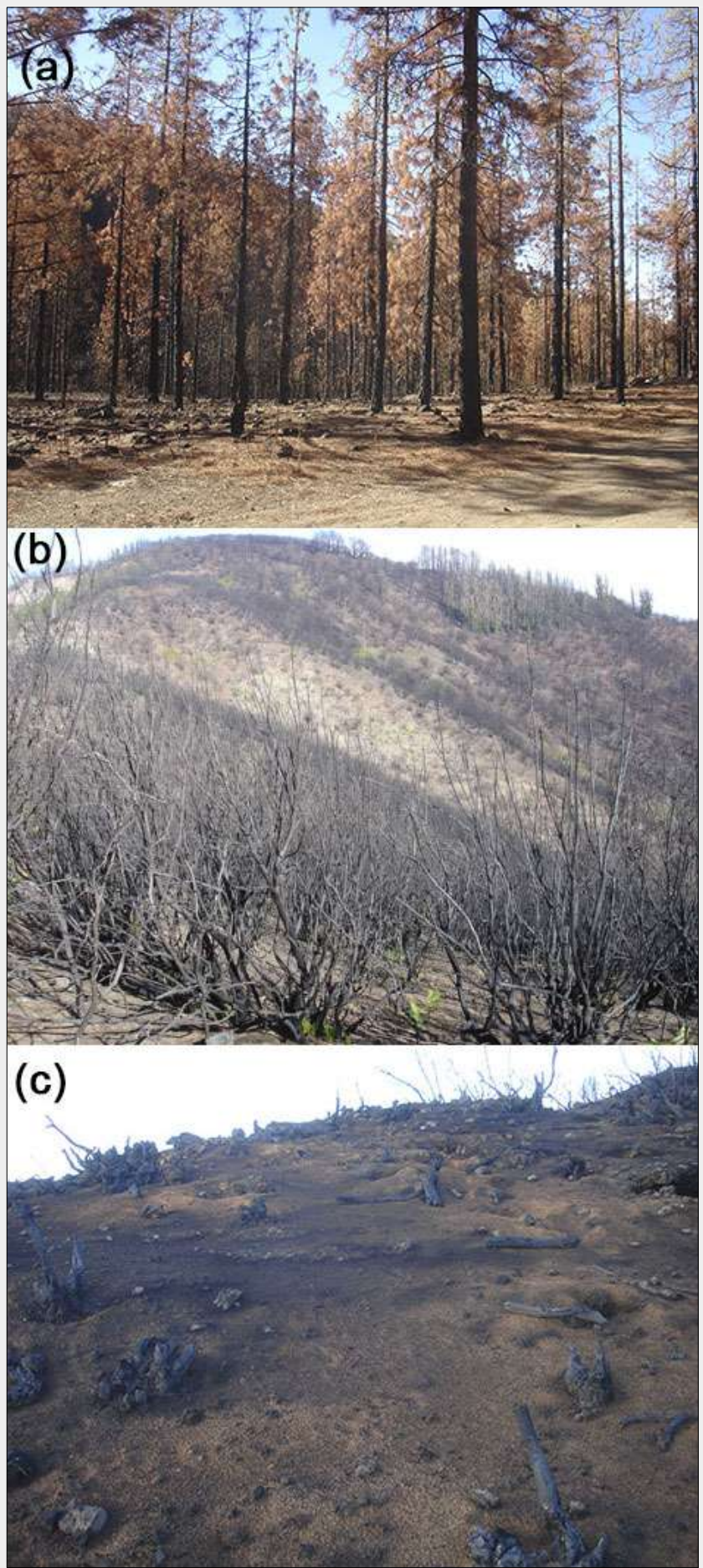

Fig. 3 - Examples of forest fires in the Canary Islands. Low (a), moderate (b) and high severity (c) according to the fire severity classification by Ryan (2002). 

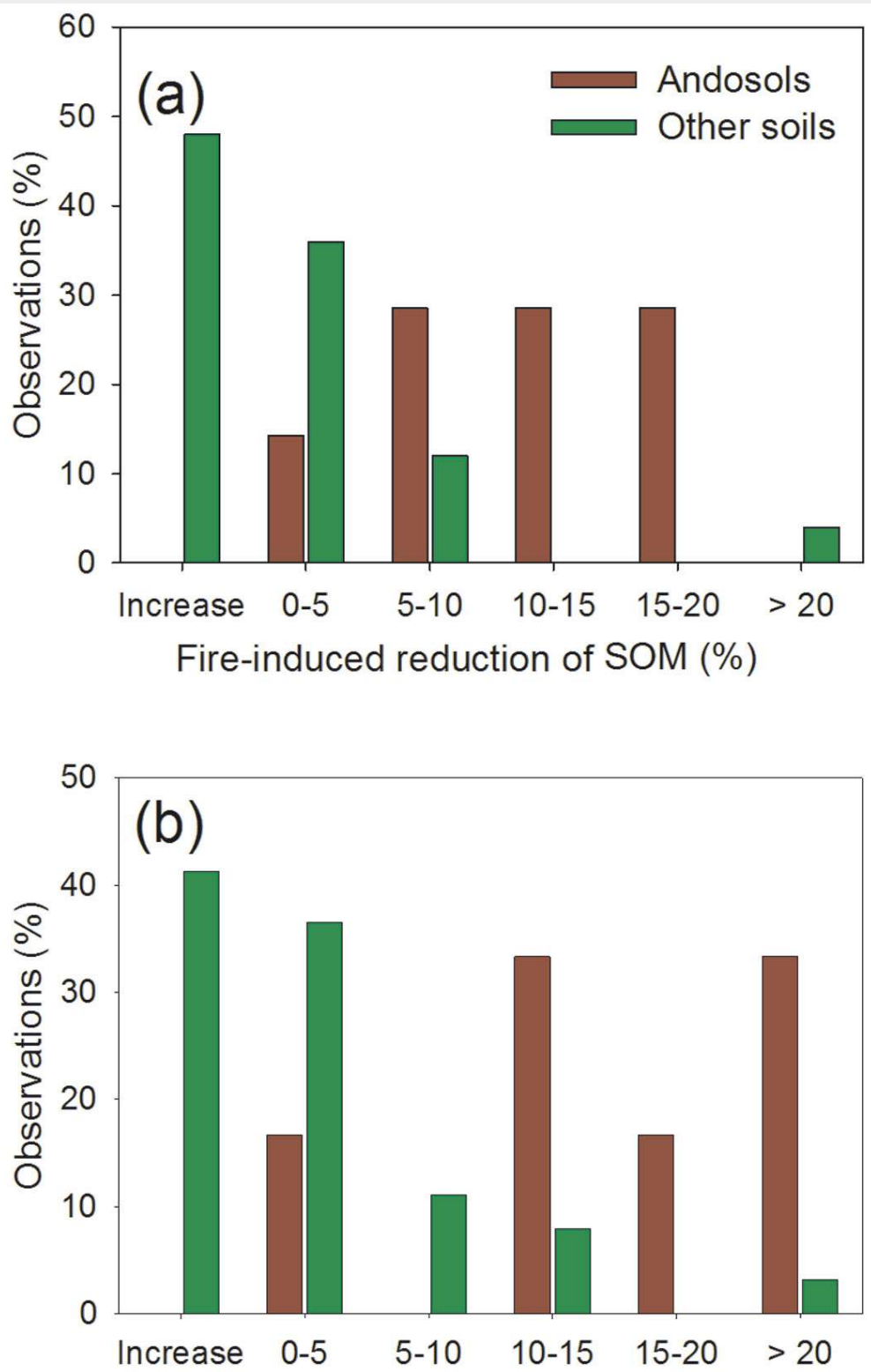

Fire-induced reduction of AS (\%)
Fig. 4 - Comparison of the impact of fire on key soil properties in Andosols (red) and other soil types (green). Distribution of results reporting fire-induced reduction/increase in (a) soil organic matter (SOM: \%) and (b) aggregate stability (AS: \%) for Andosols ( $N=7$ for SOM and $\mathrm{N}=6$ for AS) and other soil types $(\mathrm{N}=25$ for SOM and $\mathrm{N}=63$ for AS) from published data. Values calculated as Unburned value minus Burned value. Data source: Andosols (De La Rosa et al. 2013, Morales et al. 2013, Neris et al. 2013b); other soil types (Gónzalez-Pérez et al. 2004, Marcos et al. 2007, O’Dea 2007, Campo et al. 2008, Terefe et al. 2008, Are et al. 2009, Varela et al. 2010, Certini et al. 2011, Mataix-Solera et al. 2011, Badia-Villas et al. 2014).

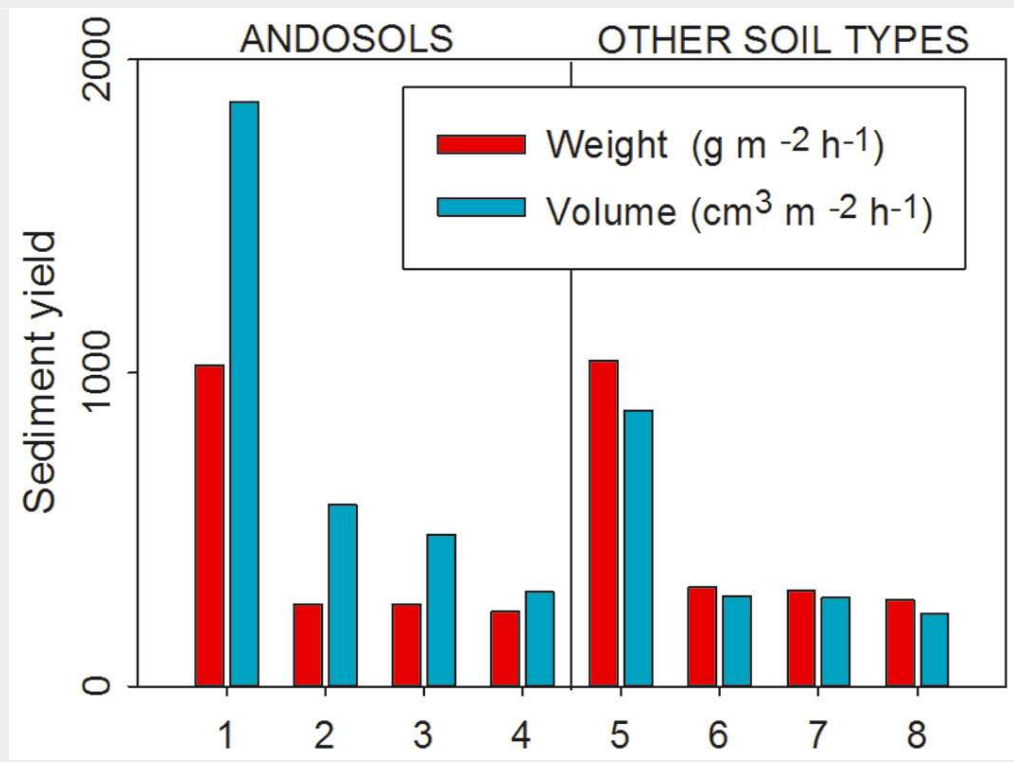

Fig. 5 - Comparison of post-fire sediment yields in Andosols and other soil types reported using rainfall simulations. Yield measured in weight (red) and volume (blue) for Andosols (left) and other soil types (right). Data source: (1): Morales et al. 2013; (2): Neris et al. 2013a; (3): Neris et al. 2013b; (4): Poulenard et al. 2001; (5): Woods \& Balfour 2008; (6): Pierson et al. 2009; (7) Cerdà \& Doerr 2008; (8): Woods \& Balfour 2008. 
(2011) in Mexican Andosols and Neris et al. (2013a) in Andosols from the Canary Islands disagree with this general trend. According to these authors, light-medium severity fires marginally enhanced surface SWR of non- or slightly-repellent Andosols, whereas SWR was greatly reduced in strongly-repellent soils after high severity fires, enhancing infiltration and reducing runoff. This response could be attributed to the different temperature reached on the soil surface during the fire (Shakesby \& Doerr 2006). Laboratory studies showed that fire can enhance SWR at temperature of $175-200{ }^{\circ} \mathrm{C}$ and destroy this feature above $270-600{ }^{\circ} \mathrm{C}$, depending on heat duration and oxygen availability but irrespec tive of soil type (DeBano et al. 1976, Doerr et al. 2004, Bryant et al. 2005).

\section{Post-fire hydrological and erosional response}

Andosols have shown a rather specific hydrological and erosional response to the impact of environmental disturbances such as land use and vegetation change that can lead to severe risk for population and properties in the Canary Islands (Rodríguez Rodríguez et al. 2002, Jiménez et al. 2003, Rodríguez et al. 2006, Neris et al. 2012) and elsewhere (Buytaert et al. 2002, 2005, Glade 2003, Jordán et al. 2009). However, the hydrological and erosional response of this soil type in the post-fire period has received little attention. Existing studies highlighted that Andosols runoff processes also show quite specific post-fire responses. In general, most authors have reported detrimental impacts of fire resulting in reduced infiltration and enhanced runoff for most soil types (Imeson et al. 1992, Cerdà et al. 1995, Rulli et al. 2006). According to Doerr et al. (2000) this response has been attributed to: (i) the fire-induced enhancement of SWR; (ii) a reduction of aggregate stability and porosity; and (iii) the reduction of vegetation cover and its protective effect. Poulenard et al. (2001) and Morales et al. (2013) also noticed a trend of reduced infiltration when studying Ecuadorian and Argentinian Andosols, respectively, with high infiltration rates in undisturbed conditions. However, Neris et al. (2013a), for Andosols from the Canary Islands, showed that high severity wildfires can also have a promoting effect on infiltration due to the reduc tion of SWR and the combustion and removal of highly water repellent surficial organic layers, which had reduced infiltration. Previous studies in the same area reported the presence of an extremely re pellent forest floor in some forested undis turbed Andosols from the Canary Islands, which reduced infiltration rate to a fifth and doubled the values of runoff-rainfall ratio (Neris et al. 2013b). Therefore, the combustion of this layer during high-severity fires can enhance infiltration, which could counteract the detrimental effect of fire on soil structure (Neris et al. 2013a).

Regarding interrill erosion processes, An- dosols follow the generally reported trend of fire-induced enhancement of soil loss, with figures from rainfall simulation experiments ranging from 30 to $2000 \mathrm{~g} \mathrm{~m}^{-2} \mathrm{~h}^{-1}$ depending on fire severity and rainfall intensity (Poulenard et al. 2001, Morales et al. 2013, Neris et al. 2013a). Most authors hypothesize that this general response may be due to: (i) the increase in runoff; (ii) the decrease in soil cover and the protective effect of vegetation and organic layers (forest floor); and (iii) the reduction in aggregate stability (Shakesby \& Doerr 2006). For Andosols, Poulenard et al. (2001) attributed the increase in soil loss to the rise in runoff and decrease in aggregate stability causing surface sealing. Neris et al. (2013a) hypothesized that the reduction in structural stability and the loss of soil cover are the key factors in the erosional response, as no significant changes were found in infiltration after the fire. Morales et al. (2013) highlight three factors (runoff, soil cover and aggregate stability) as being responsible for soil loss increase. Additionally, both Morales et al. (2013) and Neris et al. (2013a) suggest that fire severity plays a key role in the erosion process as it greatly influences the soil cover and, thus, the protection against raindrop impact and detachment by runoff in the postfire period. Soil erosion from rainfall simulation experiments by Neris et al. (2013a), Poulenard et al. (2001) and Morales et al. (2013) for fire-affected Andosols is comparable to that reported for other soil types and environments (Benavides-Solorio \& MacDonald 2001, Cerdà \& Doerr 2008, Woods \& Balfour 2008, Pierson et al. 2009). However, it has been demonstrated that Andosols' low bulk density is half or even one third of that of other fire-affected soil types (Neris et al. 2013a). Therefore, the expected volumetric soil loss can be considerably higher and its impact downslope can be catastrophic (Fig. 5). Regarding the erosion mechanism, Andosols show a distinctive behavior. According to previous studies, the erosion of this soil type is not a consequence of the dispersion of clay and transport of primary particles, but occurs mainly by detachment of small, highly water repellent, low bulk density, stable aggregates and their transport by flotation on the runoff (Poulenard et al. 2001, Rodríguez Rodríguez et al. 2002, Morales et al. 2013, Neris et al. 2013a).

As for other erosion types, several authors have reported the high susceptibility of undisturbed volcanic soils of tropical and sub-tropical areas to landslides and mudflows (Pla Sentís 1997, Rodríguez Rodríguez et al. 2002, Capra et al. 2003). These authors pointed out that the location of this soil type on steep slopes subject to torrential rains, combined with their high infiltration rate and water retention capacity, can lead to the fluidification of the soil layers, which act as triggering factors for landslides. As regards to wind erosion, most studies report that vegetation cover, soil moisture, aggregation and bulk density are key controls for this erosion type (Zobeck 1991, Michels et al. 1995, Lopez et al. 2000). To the author's knowledge, no studies focusing on the impact of fire on the occurrence of landslides or of wind erosion in Andosol terrains are available in the literature. However, the hypothesis that wildfires can act as triggering factors for both erosion types is supported by scientific evidences and historic events. On one hand, several reported fire-impacts on the ecosystem may induce both landslides (such as an increase in Andosols' infiltration, water retention capacity at low pressures and a reduction in soil cohesiveness) and wind erosion (such as a severe reduction in forest canopy, litter, soil bulk density and soil aggregation, and an increase in dry conditions). On the other, the catastrophic landslides and mudflows occurred in the Canary Islands and elsewhere in the world suggest that nowadays they are potential threats to lives and infrastructures. Therefore, more studies are needed to address this knowledge gap.

\section{Post-fire restoration and mitigation strategies in Andosols of the Canary Islands}

Fire prevention and post-fire mitigation actions are the main strategies used by the agencies responsible of forest conservation and land management in the Canary Islands (the Cabildos), to avoid or reduce fire impacts on soil hydrology and erosion response. The information summarized in this section is based on the approaches adopted in the post-fire period by the Cabildo de Tenerife and Cabildo de La Palma. For these management bodies, post-fire restauration actions start with the evaluation of the impact of fire on environmental characteristics and functions, the prediction of the likely consequences and derived risks, and the organization of restoration and mitigation actions to reduce the expected impacts. Due to the particular characteristics of the Canary Islands (steep forested slopes, soils highly susceptible to fire impacts, frequent rainstorms in autumn and winter, and high population density downslope), the restoration and mitigation efforts are aimed at addressing three main objectives in the following order: (i) to mitigate the impact of fire on the hydrological and erosional response in order to reduce the risk to lives and infrastructures onsite and offsite; (ii) to restore the landscape aesthetics and other ecological functions; (iii) to manage the remaining fuel load in order to limit the occurrence of new wildfires. As regard the mitigation treatments, reforestation is not usually included in restoration programmes in the Andosols of the Canary Islands, though the use of vegetation to increase soil protection against erosion and surface runoff is a common action in fire affected areas worldwide. This is due to the high fire resistance and sprouting capacity of the main forest species present 


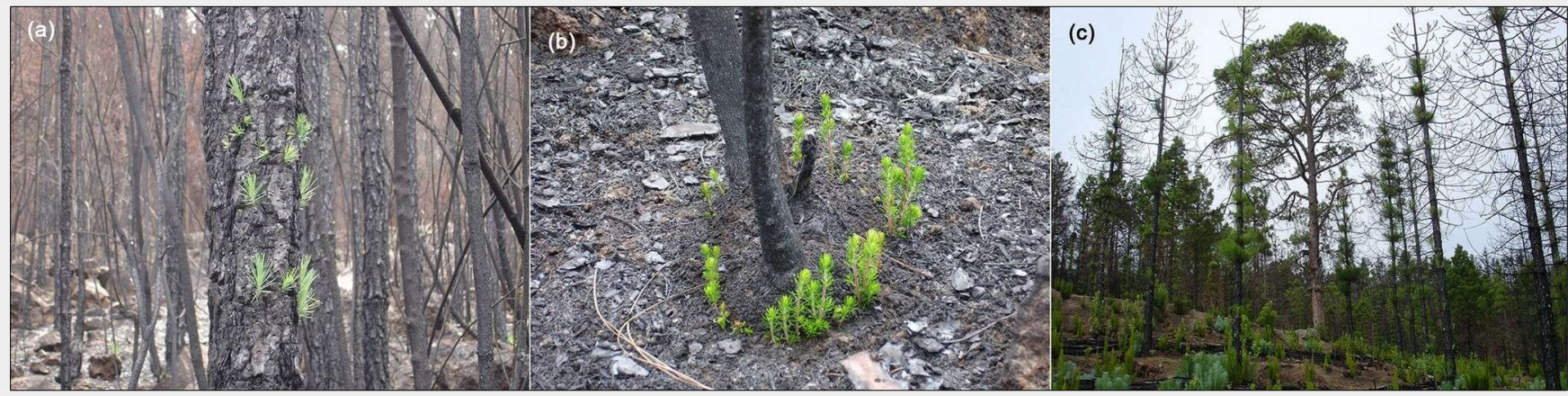

Fig. 6 - Examples of sprouting behavior of forest species after a wildfire. Pinus canariensis (a) and Erica sp. (b) sprouting 3 months after the forest fire. Forest recovery 1 year after the forest fire (c).

in forested areas that experience frequent fires (Fig. 6). Pinus canariensis, the endemic pine species in the Canary Islands, shows several fire adaptations including thick bark and buds, long needles, tall growth habit and sprouting capacity (Climent et al. 2004). Additionally, one of the main genus present in the Canarian rainforest, Erica, also exhibits high sprouting capacity after fire (Lloret \& Vila 2003). According to the aforementioned agencies, the fast recovery after fire makes reforestation unnecessary. Instead, silvicultural practices on the affected area are carried out, including the removal of dead individuals and the pruning of charred branches of surviving trees to reduce infestation threats and strengthen their recovery (Fig. 7). However, recent observations after a forest fire that affected La Gomera in 2012 suggest that these silvicultural practices could delay vegetation recovery after fire. In order to clarify this point, a specific monitoring programme is currently in place.

In addition to the traditional channel treatments, an innovative structure adapted to local conditions, called rock and biomass mixed dam, was developed after a forest fire in Tenerife that burned 17000 ha in the summer of 2007 (Ministerio de Medio Ambiente y Medio Rural y Marino 2008). Due to the magnitude of the wildfire and the resulting risks, the structure was designed to be low-cost, easy and rapid to be implemented to reduce hydrological risks. The mixed dam is a temporary structure that combines different mitigation techniques such as contour logs, contour trenches and rock dams. Similarly to other channel treatments, its main objective is to reduce water velocity and enhance infiltration and sediment deposition. The mixed dam consists of vegetal debris used as vertical stakes (mainly burned logs of Erica sp. and Myrica faya) and horizontal logs (mainly from burned Pinus canariensis) and biodegradable rope to tie the stakes and logs together as a trench and to anchor the whole structure to adjacent trees. The trench is reinforced on the outside by the rock slope to gain stability (less than $50 \%$ slope angle) and filled on the inside with vegetal debris obtained from silvicultural work and topped again with rocks (Fig. 8). Its dimensions vary depending on the channel width, although always ranging from 1 to $2 \mathrm{~m}$ in height and 8 to 10 $\mathrm{m}$ in width. A prediction of the maximum water flow and water level expected in the post-fire period are essential to design these structures. Additionally, the rock density, the resistance to flexion of the wood stakes and logs, the resistance reduction coefficients and the load increase coefficients for both permanent (structure weight) and temporary loads

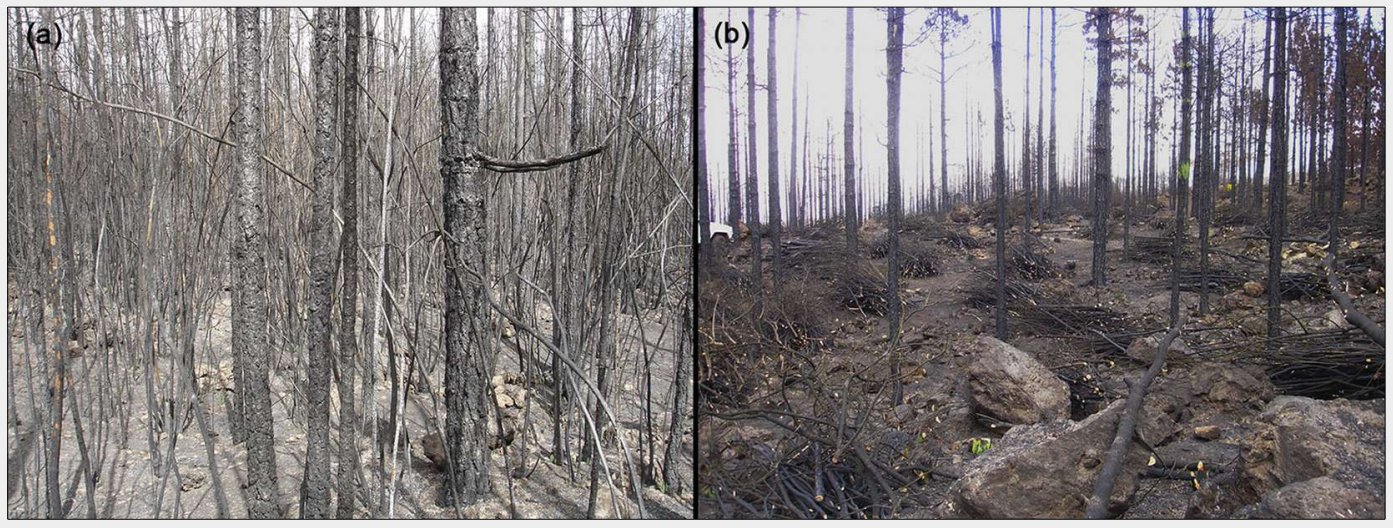

Fig. 7 - Example of restoration works after the large forest fire of 2007 in Tenerife. Fireaffected forest area before (a) and after (b) silvicultural practices.

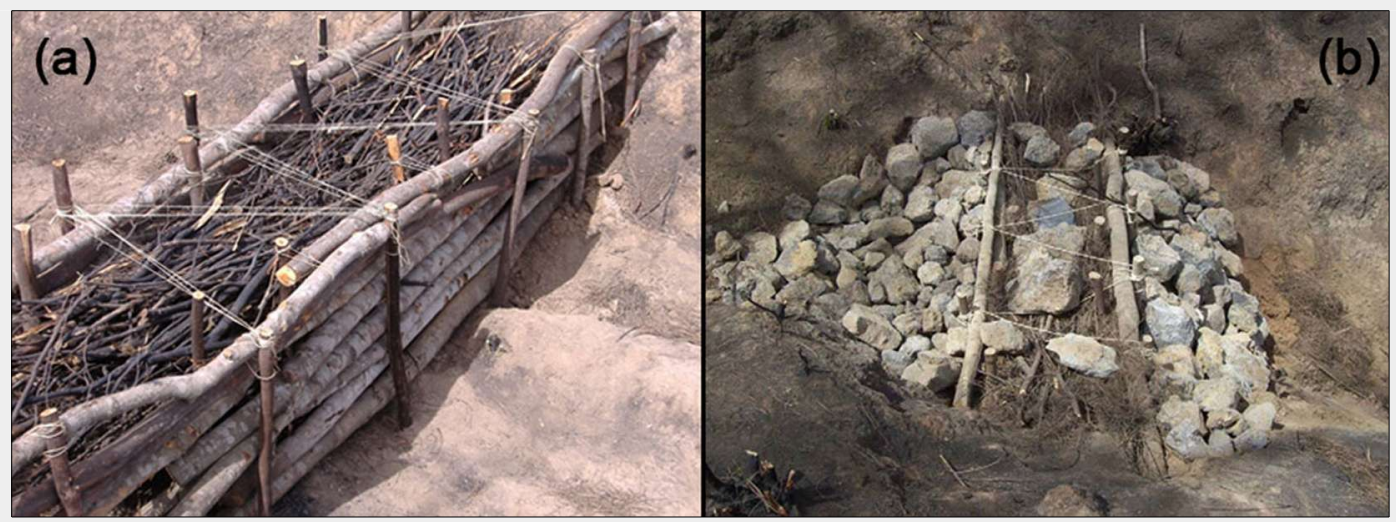

Fig. 8 - Construction process of the rock and biomass mixed dam. Trench constructed and filled with debris from the silvicultural works (a) and reinforced by rocks (b). 
(water flow) are taken into account in their design. The distance between these structures in a channel is determined according to the structures' height and the channel slope angle (Tardío Cerrillo \& Caballero Serrano 2009).

This structure is usually used as a principal treatment in ephemeral or small-order channels and as a secondary treatment complementing rock dams and gabions in larger channels. Due to the biodegradable nature of most of their components, these structures can also facilitate colonization by plants (Tardío Cerrillo \& Caballero Serrano 2009 - Fig. 9). This innovative structure has several useful features: (i) it reduces the channel slope and, thus, water speed and detachment capacity; (ii) promotes infiltration and sedimentation; iii) economizes resources and time by using on-site material for its construction; (iv) enhances the colonization of vegetation due to the biodegradable nature of most of its components. The advantages attributable to this mixed dam are: (i) notable sediment storage capacity, mainly large material as vegetal debris or rocks; (ii) high adaptability of the design and the components used to the environment conditions; (iii) notable vegetation recovery and colonization of the channels due to the nature of its components.

Regarding hillslope treatments, the construction of erosion barriers to reduce runoff and sediment transport is the most used mitigation action in the Canary Islands. It includes contour-felled logs and small dams constructed using vegetal material, mainly small burned logs and branches obtained from the silvicultural work (Fig. 10). Due to budget constraints, no monitoring programmes have been put in place to evaluate the effectiveness of these treatments for Andosols. However, erosion barriers, widely used at the beginning of the century as an effective on-site control of runoff and erosion in Spain (Fernández et al. 2011, Badia et al. 2015, Ferreira et al. 2015) and elsewhere (Raftoyannis \& Spanos 2005, Robichaud et al. 2008, Myronidis et al. 2010, Ahn et al. 2013, Aristeidis \& Vasiliki 2015), have been replaced lately by dry mulch treatments by land managers. This treatment aims to provide cover to the mi-

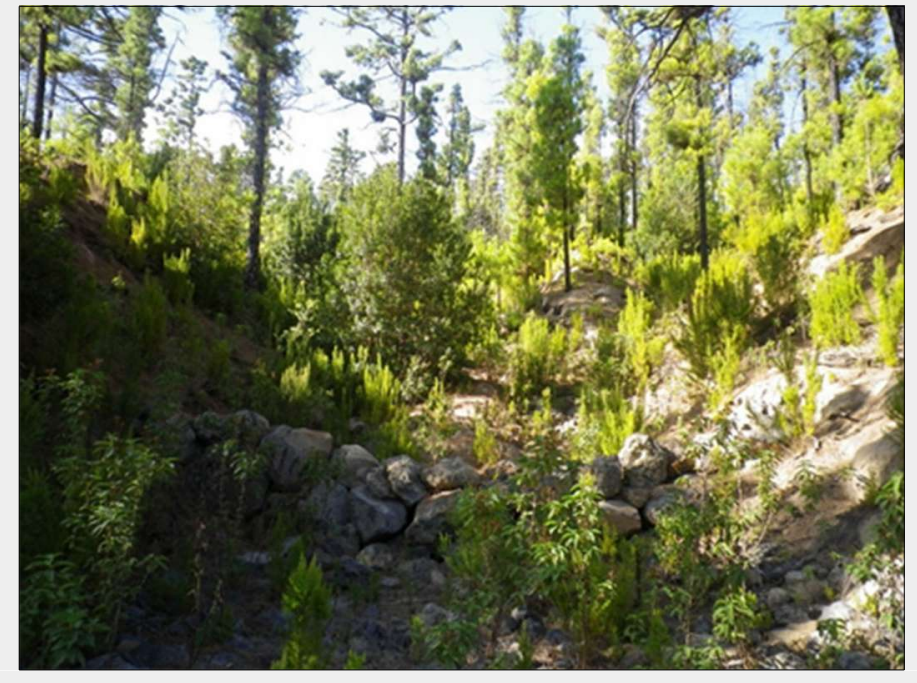

Fig. 9 - A mixed dam structure built in Tenerife after the large wildfire of 2007 , colonized by forest species one year after its construction.

neral soil, since most studies indicate that Andosols. the proportion of bare soil is the main driving factor of soil erosion in the post-fire period (Robichaud et al. 2010). In spite of these new insights, no surface treatments like mulching are commonly used in Andosol terrain on the Canary Islands due to: (i) the generally rapid recovery of the main species of forested areas in the Archipelago (Pinus canariensis and Erica sp.), which provide a litter layer to protect the mineral soil; and (ii) the higher cost of surface treatments. However, as reported by Neris et al. (2013a), the recovery of the protective soil organic layers after a wildfire in pine forest can be delayed by the effect of high severity crown fires. These authors found two different situations after the fire according to fire severity. After surface fires of light to moderate severity, the soil surface is rapidly covered by pine needles from the scorched crowns, and erosion processes increase slightly in comparison to unburned areas. However, after crown fires of high severity, the soil surface is generally completely bare during the first post-fire year and the soil loss rate increases by up to three orders of magnitude (Morales et al. 2013, Neris et al. 2013a). This suggests that the application and evaluation of innovative surface treatments which have been highly effective in different terrains could also be also applied to

\section{Conclusions and perspectives}

This review examined the main studies and management approaches related to the impact of forest fires on the hydrological and erosional responses of Andosols of the Canary Islands (Spain) within the context of the global knowledge, in order to identify main findings, knowledge gaps and promising new lines of research for reducing risks in the post-fire period.

Andosol terrains are frequently located on steep slopes of volcanic areas with high annual precipitation, regular rainstorms and dense fire-prone forest cover situated above heavily-populated areas. The existing limited knowledge on the impact of fire on key properties of Andosols suggests that their response to fire is: (i) similar to other soil types but magnified by soil properties such as SOM, aggregate stability or pore size distribution; (ii) significantly different from other soil types in soil properties such as bulk density or SWR, which show the opposite trend to non-volcanic soils. Such divergences in understanding and predicting soil hydrological response to fire based on key soil properties highlight that further research is needed in order to establish the base knowledge necessary for effectively predicting and mitigating future risks.

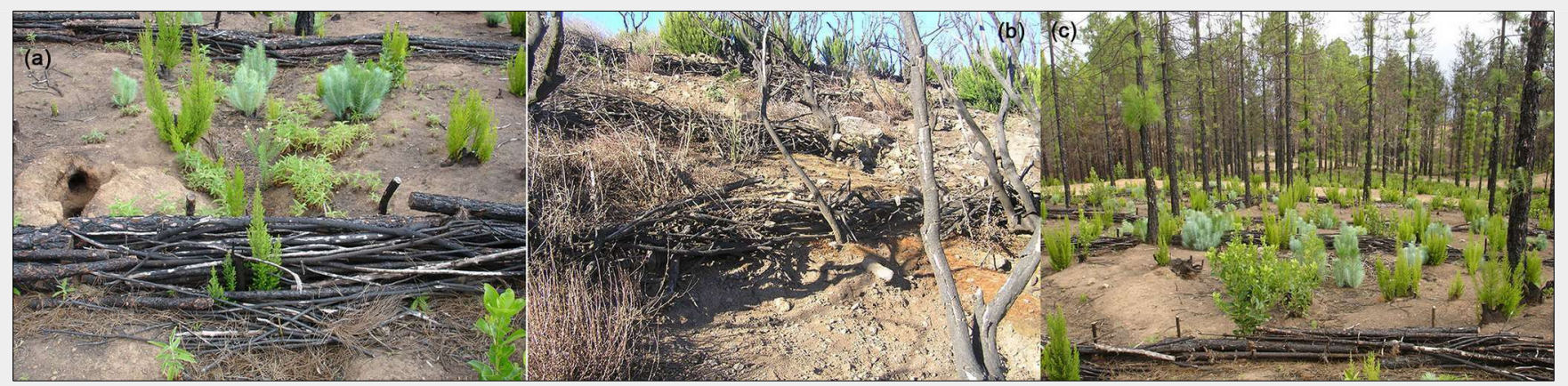

Fig. 10 - Example of surface treatments after the large wildfire of 2007 in Tenerife. Small dams built using on-hand logs and branches. 
The existing studies on the hydrological and erosional response of Andosols to fire highlighted an increased soil loss rate, as expected due to their low bulk density. However, those studies are few and limited to the evaluation at microplot scale. Additionally, little attention has been given to date to the impact of fire on other important erosion types such as wind erosion and landslides. These research gaps should be addressed by evaluating the response of Andosols at different scales and to different erosion types with the aim of developing prediction and mitigation tools for disaster risk reduction.

In the Canary Islands, silvicultural practices aimed at reducing infestation threats have replaced reforestation actions due to the high resprouting capacity of the main species present in their fire-prone areas. Traditional slope treatments such as contour-felled logs and log dams are used in the post-fire period, along with a new and inexpensive channel treatment consisting of a mixed dam of stones and biomass. However, the effectiveness and cost-benefit ratio of the classical and novel mitigation treatments used has not been assessed to date. Furthermore, innovative surface treatments such as dry mulching or seeding, largely applied in other terrain types, have not been tested either in Canary Islands or other Andosol terrain elsewhere.

Given the importance of Andosols in densely populated areas, it is essential to address these knowledge gaps in order to allow development of cost-effective approaches for mitigating accelerated hydrological and erosional events after fire in volcanic areas around the world.

\section{Acknowledgements}

This research was funded by the $\mathrm{H} 2 \mathrm{O} 20$ Marie Sklodowska - Curie Individual Fellowship 2014 "FireAndRiskPrevention" from the European Commission (project number 655993).

\section{References}

Ahn Y-S, Otsuki K, Ryu S-R, Chun K-W, An K-W, Lee K-H, Choi H-T, Mizugaki S, Seo J-I (2013). Surface erosion control by contour-felled log erosion barriers in post fire areas in eastern coastal regions of the republic of korea. Journal of the Faculty of Agriculture Kyushu University 58 (2): 389-394.

Are KS, Oluwatosin GA, Adeyolanu OD, Oke AO (2009). Slash and burn effect on soil quality of an Alfisol: soil physical properties. Soil and Tillage Research 103 (1): 4-10. - doi: 10.1016/j.still. 2008.08.011

Aristeidis K, Vasiliki K (2015). Evaluation of the post-fire erosion and flood control works in the area of cassandra (Chalkidiki, north Greece). Journal of Forestry Research 26 (1): 209-217. doi: 10.1007/s11676-014-0005-9

Badia-Villas D, Gonzalez-Perez JA, Aznar JM, Arjona-Gracia B, Marti-Dalmau C (2014). Changes in water repellency, aggregation and organic matter of a mollic horizon burned in labo- ratory: Soil depth affected by fire. Geoderma 213: 400-407. - doi: 10.1016/j.geoderma.2013.08. 038

Badia D, Sanchez C, Aznar JM, Marti C (2015). Post-fire hillslope log debris dams for runoff and erosion mitigation in the semiarid ebro basin. Geoderma 237: 298-307. - doi: 10.1016/j. geoderma.2014.09.004

Barreto P (1979). Los Llanos de Aridane sin agua potable [Los Llanos de Aridane without potable water]. In: "Diario de Avisos", vol. 27.01. 1979, Tenerife, Spain, pp. 27.

Benavides-Solorio J, MacDonald LH (2001). Postfire runoff and erosion from simulated rainfall on small plots, Colorado Front Range. Hydrological Processes 15 (15): 2931-2952. - doi: 10.1002/ hyp. 383

Bryant R, Doerr SH, Helbig M (2005). Effect of oxygen deprivation on soil hydrophobicity during heating. International Journal of Wildland Fire 14 (4): 449-455. - doi: 10.1071/wfo5035

Buytaert W, Deckers J, Dercon G, De Bievre B, Poesen J, Govers G (2002). Impact of land use changes on the hydrological properties of volcanic ash soils in south Ecuador. Soil Use and Management 18 (2): 94-100. - doi: 10.1079/sum 2001107

Buytaert W, Wyseure G, De Bievre B, Deckers J (2005). The effect of land-use changes on the hydrological behaviour of histic Andosols in south Ecuador. Hydrological Processes 19 (20): 3985-3997. - doi: 10.1002/hyp.5867

Campo J, Gimeno-Garcia E, Andreu V, GonzalezPelayo O, Rubio JL (2008). Aggregation of under canopy and bare soils in a Mediterranean environment affected by different fire intensities. Catena 74 (3): 212-218. - doi: 10.1016/j.ca tena.2008.05.002

Candan F, Broquen P (2009). Aggregate stability and related properties in NW Patagonian Andisols. Geoderma 154 (1-2): 42-47. - doi: 10.1016/j. geoderma.2009.09.010

Capra L, Lugo-Hubp J, Borselli L (2003). Mass movements in tropical volcanic terrains: The case of Teziutlán (México). Engineering Geology 69(3-4): 359-379. - doi: 10.1016/S0013-7952 (03)00071-1

Cerdà A, Doerr SH (2008). The effect of ash and needle cover on surface runoff and erosion in the immediate post-fire period. Catena 74 (3): 256-263. - doi: 10.1016/j.catena.2008.03.010

Cerdà A, Imeson AC, Calvo A (1995). Fire and aspect induced differences on the erodibility and hydrology of soils at La-Costera, Valencia, southeast Spain. Catena 24 (4): 289-304. - doi: 10.1016/0341-8162(95)00031-2

Certini G, Nocentini C, Knicker H, Arfaioli P, Rumpel C (2011). Wildfire effects on soil organic matter quantity and quality in two fire-prone Mediterranean pine forests. Geoderma 167- 68: 148-155. - doi: 10.1016/j.geoderma.2011.09.005 Climent J, Tapias R, Pardos JA, Gil L (2004). Fire adaptations in the Canary islands pine (Pinus canariensis). Plant Ecology 171 (1-2): 185-196. doi: 10.1023/B:VEGE.0000029374.64778.68

De La Rosa JM, Gonzalez-Perez JA, Gonzalez-Vila FJ, Knicker H (2013). Medium term effects of fire induced soil organic matter alterations on Andosols under canarian pine (Pinus canariensis). Journal of Analytical and Applied Pyrolysis 104: 269-279. - doi: 10.1016/j.jaap.2013.07.006
DeBano LF, Savage SM, Hamilton DA (1976). Transfer of heat and hydrophobic substances during burning. Soil Science Society of America Journal 40 (5): 779-782. - doi: 10.2136/sssaj1976. $03615995004000050043 x$

Doerr SH, Blake WH, Shakesby RA, Stagnitti F, Vuurens SH, Humphreys GS, Wallbrink P (2004). Heating effects on water repellency in Australian eucalypt forest soils and their value in estimating wildfire soil temperatures. International Journal of Wildland Fire 13 (2): 157-163. doi: 10.1071/wfo3051

Doerr SH, Shakesby RA, Blake WH, Chafer CJ, Humphreys GS, Wallbrink PJ (2006). Effects of differing wildfire severities on soil wettability and implications for hydrological response. Journal of Hydrology 319(1-4): 295-311. - doi: 10.1016/j.jhydrol.2005.06.038

Doerr SH, Shakesby RA, Walsh RPD (2000). Soil water repellency: its causes, characteristics and hydro-geomorphological significance. Earth-Science Reviews 51 (1-4): 33-65. - doi: 10.1016/Soo 12-8252(00)00011-8

Dorner J, Dec D, Peng X, Horn R (2009). Change of shrinkage behavior of an Andisol in southern Chile: effects of land use and wetting/drying cycles. Soil and Tillage Research 106 (1): 45-53. doi: 10.1016/j.still.2009.09.013

Dorner J, Dec D, Peng X, Horn R (2010). Effect of land use change on the dynamic behaviour of structural properties of an Andisol in southern Chile under saturated and unsaturated hydraulic conditions. Geoderma 159(1-2): 189-197. doi: 10.1016/j.geoderma.2010.07.011

Driessen P, Deckers J, Spaargaren O, Nachtergaele $F$ (2001). Lecture notes on the major soils of the world. FAO, Rome, Italy, pp. 52.

Fernández C, Vega JA, Jimenez E, Fonturbel T (2011). Effectiveness of three post-fire treatments at reducing soil erosion in Galicia (NW Spain). International Journal of Wildland Fire 20 (1): 104-114. - doi: 10.1071/wfogo10

Ferreira AJD, Alegre SP, Alves Coelho CO, Shakesby RA, Pascoa FM, Santos Ferreira CS, Keizer JJ, Ritsema C (2015). Strategies to prevent forest fires and techniques to reverse degradation processes in burned areas. Catena 128: 224-237. - doi: 10.1016/j.catena.2014.09.002 Giovannini G, Lucchesi S (1997). Modifications induced in soil physico-chemical parameters by experimental fires at different intensities. Soil Science 162 (7): 479-486. - doi: 10.1097/00010 694-199707000-00003

Glade T (2003). Landslide occurrence as a response to land use change: a review of evidence from New Zealand. Catena 51(3-4): 297-314. doi: 10.1016/s0341-8162(02)00170-4 Gónzalez-Pérez JA, Gónzalez-Vila FJ, Almendros $\mathrm{G}, \mathrm{Knicker} H$ (2004). The effect of fire on soil organic matter - a review. Environment International 30 (6): 855-870. - doi: 10.1016/j.envint.20 04.02.003

Hernández-Moreno JM, Tejedor ML, Jiménez CC (2007). Effects of land use on soil degradation and restoration in the Canary islands. In: "Soils of volcanic regions in Europe" (Arnalds O, Bartoli F, Buurman P, ÓskarsonH, Stoops G, GarcíaRodeja E eds). Springer, Berlin, Germany, pp. 565-579. - doi: 10.1007/978-3-540-48711-1_39 Hoyos N, Comerford NB (2005). Land use and landscape effects on aggregate stability and 
total carbon of Andisols from the Colombian Andes. Geoderma 129 (3-4): 268-278. - doi: 10.1016/j.geoderma.2005.01.002

Imeson AC, Verstraten JM, Vanmulligen EJ, Sevink J (1992). The effects of fire and water repellency on infiltration and runoff under Mediterranean type forest. Catena 19 (3-4): 345361. - doi: 10.1016/0341-8162(92)90008-Y Instituto Canario de Estadística (2015). Estadística de incendios forestales en Canarias [Statistics of forest fires in Canary Islands]. Gobierno de Canarias, Tenerife, Spain. [in Spanish] [online] URL: http://www.gobiernodecanarias.org/ istac/temas_estadisticos/territorioymedioambi ente/

IUSS Working Group WRB (2014). World reference base for soil resources 2014. International soil classification system for naming soils and creating legends for soil maps. FAO, Rome, Italy, pp. 146-147.

Jiménez C, Tejedor M, Morillas G, Neris J (2003). Infiltration rates in Andisols of the Island of Tenerife (Canary islands, Spain). In: Proceedings of the International Symposium " 25 Years of Assessment of Erosion" (Gabriels D, Cornelis WM eds). University of Ghent, Ghent, Belgium, pp. 157-158.

Jiménez C, Tejedor M, Morillas G, Neris J (2006). Infiltration rate in Andisols: effect of changes in vegetation cover (Tenerife, Spain). Journal of Soil and Water Conservation 61 (3): 153-158. [online] URL: http://www.jswconline.org/con tent/61/3/153.short

Jordán A, Martínez Zavala L, Nava AL, Alanís N (2009). Occurrence and hydrological effects of water repellency in different soil and land use types in Mexican volcanic highlands. Catena 79 (1): 60-71. - doi: 10.1016/j.catena.2009.05.013

Jordán A, Martínez Zavala L, Mataix-Solera J, Nava AL, Alanis N (2011). Effect of fire severity on water repellency and aggregate stability on Mexican volcanic soils. Catena 84 (3): 136-147. doi: 10.1016/j.catena.2010.10.007

Letey J (2001). Causes and consequences of fireinduced soil water repellency. Hydrological Processes 15 (15): 2867-2875. - doi: 10.1002/hyp.378 Lopez MV, Gracia R, Arrue JL (2000). Effects of reduced tillage on soil surface properties affecting wind erosion in semiarid fallow lands of Central Aragon. European Journal of Agronomy 12 (3-4): 191-199. - doi: 10.1016/s1161-0301(00) 00046-0

Lloret F, Vila M (2003). Diversity patterns of plant functional types in relation to fire regime and previous land use in Mediterranean woodlands. Journal of Vegetation Science 14 (3): 387398. - doi: 10.1111/j.1654-1103.2003.tbo2164.x

Marcos E, Tarrega R, Luis E (2007). Changes in a humic cambisol heated (100-500 degrees C) under laboratory conditions: the significance of heating time. Geoderma 138 (3-4): 237-243. doi: 10.1016/j.geoderma.2006.11.017

Marzol Jaén MV (1988). La lluvia, un recurso natural para Canarias [Rain, a natural resource for Canary Islands]. Servicio de Publicaciones de la Caja General de Ahorros de Canarias, Santa Cruz de Tenerife, Spain, pp. 220.

Mataix-Solera J, Cerdà A, Arcenegui V, Jordán A, Martínez-Zavala $L$ (2011). Fire effects on soil aggregation: a review. Earth-Science Reviews 109 (1-2): 44-6o. - doi: 10.1016/j.earscirev.2011.08.002
Michels K, Sivakumar MVK, Allison BE (1995). Wind erosion control using crop residue. 1. Effects on soil flux and soil properties. Field Crops Research 40 (2): 101-110. - doi: 10.1016/03 78-4290(94)00094-s

Ministerio de Medio Ambiente y Medio Rural y Marino (2008). Diseño de obras transversales: diques mixtos de mampostería y biomasa residual [Design of channel treatments: rock and biomass mixed dams]. Inventario de Tecnologías Disponibles en España para la Lucha contra la Desertificación, Gobierno de España, Madrid, Spain, pp. 5.

Morales D, Rostagno CM, La Manna L (2013). Runoff and erosion from volcanic soils affected by fire: the case of Austrocedrus chilensis forests in Patagonia, Argentina. Plant and Soil 370 (1-2): 367-380. - doi: 10.1007/s11104-013-16 40-1

Myronidis DI, Emmanouloudis DA, Mitsopoulos IA, Riggos EE (2010). Soil erosion potential after fire and rehabilitation treatments in Greece. Environmental Modeling and Assessment 15 (4): 239-250. - doi: 10.1007/s10666-009-9199-1 Nanzyo M, Shoji S, Dahlgren R (1993). Physical characteristics of volcanic ash soils. In: "Volcanic Ash Soils: Genesis, Properties and Utilization" (Shoji S, Nanzyo M, Dahlgren R eds). Elsevier Science Publishers BV, Amsterdam, The Netherlands, pp. 288.

Neall VE (2006). Volcanic soils. In: “Land use and land cover, Encyclopedia of life support systems (EOLSS) Vol. VII" (Verheye W ed). Eolss Publishers/UNESCO, Oxford, UK, pp. 24.

Neris J, Jiménez C, Fuentes J, Morillas G, Tejedor $M$ (2012). Vegetation and land-use effects on soil properties and water infiltration of Andisols in Tenerife (Canary islands, Spain). Catena 98: 55-62. - doi: 10.1016/j.catena.2012.06.006 Neris J, Tejedor M, Fuentes J, Jiménez C (2013a). Infiltration, runoff and soil loss in Andisols affected by forest fire (Canary islands, Spain). Hydrological Processes 27 (19): 2814-2824. - doi: 10.1002/hyp.9403

Neris J, Tejedor M, Rodríguez M, Fuentes J, Jiménez C (2013b). Effect of forest floor characteristics on water repellency, infiltration, runoff and soil loss in Andisols of Tenerife (Canary islands, Spain). Catena 108: 50-57. - doi: 10.1016/ j.catena.2012.04.011

Neris J, Doerr SH, Tejedor M, Jiménez C, Hernández-Moreno JM (2014). Thermal analysis as a predictor for hydrological parameters of fireaffected soils. Geoderma 235-236: 240-249. doi: 10.1016/j.geoderma.2014.07.018

Notario del Pino JS (2009). Los incendios forestales en Canarias: una revisión. Causas, particularidades e impactos sobre el suelo [Forest fires in Canary Islands: a review. Causes, characteristics and impacts on soils]. In: "Efectos de los incendios forestales sobre los suelos en España. El estado de la cuestión visto por los científicos españoles" (Cerdà A, Mataix-Solera J eds). Cátedra de divulcagión científica, Universitat de València, Valencia, Spain, pp. 469489.

O'Dea ME (2007). Influence of mycotrophy on native and introduced grass regeneration in a semiarid grassland following burning. Restoration Ecology 15 (1): 149-155. - doi: 10.1111/j.1526100X.2006.00199.X
Perrin JL, Bouvier C, Janeau JL, Menez G, Cruz F (2001). Rainfall/runoff processes in a small periurban catchment in the Andes mountains. The Rumihurcu Quebrada, Quito (Ecuador). Hydrological Processes 15 (5): 843-854. - doi: 10.1002/ hyp. 190

Pierson FB, Moffet CA, Williams CJ, Hardegree SP, Clark PE (2009). Prescribed-fire effects on rill and interrill runoff and erosion in a mountainous sagebrush landscape. Earth Surface Processes and Landforms 34 (2): 193-203. - doi: 10.1002/esp.1703

Pla Sentís I (1997). A soil water balance model for monitoring soil erosion processes and effects on steep lands in the tropics. Soil Technology 11 (1): 17-30. - doi: 10.1016/so933-3630(96) 00112-2

Poulenard J, Podwojewski P, Janeau JL, Collinet $J$ (2001). Runoff and soil erosion under rainfall simulation of Andisols from the Ecuadorian Páramo: Effect of tillage and burning. Catena 45 (3): 185-207. - doi: 10.1016/S0341-8162(01)001485

Raftoyannis Y, Spanos I (2005). Evaluation of log and branch barriers as post-fire rehabilitation treatments in a Mediterranean pine forest in Greece. International Journal of Wildland Fire 14 (2): 183-188. - doi: 10.1071/wfo4031

Rahman MH, Okubo A, Sugiyama S, Mayland HF (2008). Physical, chemical and microbiological properties of an Andisol as related to land use and tillage practice. Soil and Tillage Research 101 (1-2): 10-19. - doi: 10.1016/j.still.2008.05.006

Redacción (1990). Fuertes precipitaciones en la madrugada de ayer [Heavy rainfall yesterday in the small hours]. In: "Diario de Avisos". Vol. 02.12.1990, Tenerife, Spain, pp. 20.

Robichaud PR, Ashmun LE, Sims BD (2010). Postfire treatment effectiveness for hillslope stabilization. Report 63, Rocky Mountain Research Station, USDA Forest Service, Fort Collins, CO, USA, pp. 20. [online] URL: http://digitalcommo ns.unl.edu/jfspresearch/41/

Robichaud PR, Pierson FB, Brown RK, Wagenbrenner JW (2008). Measuring effectiveness of three postfire hillslope erosion barrier treatments, western Montana, USA. Hydrological Processes 22 (2): 159-170. - doi: 10.1002/hyp.65 58

Rodríguez AR, Arbelo CD, Guerra JA, Mora JL, Notario JS, Armas CM (2006). Organic carbon stocks and soil erodibility in Canary islands Andosols. Catena 66 (3): 228-235. - doi: 10.1016/ j.catena.2006.02.001

Rodríguez Rodríguez A, Guerra JA, Gorrín SP, Arbelo CD, Mora JL (2002). Aggregates stability and water erosion in Andosols of the Canary islands. Land Degradation and Development 13 (6): 515-523. - doi: 10.1002/ldr.543

Rulli MC, Bozzi S, Spada M, Bocchiola D, Rosso R (2006). Rainfall simulations on a fire disturbed Mediterranean area. Journal of Hydrology 327 (3-4): 323-338. - doi: 10.1016/j.jhydrol.2005.11.037 Ryan KC (2002). Dynamic interactions between forest structure and fire behavior in boreal ecosystems. Silva Fennica 36 (1): 13-39. - doi: 10.142 14/sf.548

Shakesby RA, Doerr SH (2006). Wildfire as a hydrological and geomorphological agent. Earth-Science Reviews 74 (3-4): 269-307. - doi: 10.1016/j.earscirev.2005.10.006 
Stoof CR, Wesseling JG, Ritsema CJ (2010). Effects of fire and ash on soil water retention. Geoderma 159(3-4): 276-285. - doi: 10.1016/j.geoderma.2010.08.002

Tardío Cerrillo G, Caballero Serrano C (2009). Nuevo elemento para controlar la erosión [New structure to control soil erosion]. In: Proceedings of the " 9 " Congreso Nacional del Medio Ambiente (CONAMA)". Madrid (Spain) 15 Dec 2008. Fundación CONAMA, Madrid, Spain, pp. 23.

Terefe T, Mariscal-Sancho I, Peregrina F, Espejo $R$ (2008). Influence of heating on various properties of six Mediterranean soils. A laboratory study. Geoderma 143 (3-4): 273-280. - doi: 10.1016/j.geoderma.2007.11.018

Varela ME, Benito E, Keizer JJ (2010). Effects of wildfire and laboratory heating on soil aggregate stability of pine forests in Galicia: the role of lithology, soil organic matter content and water repellency. Catena 83 (2-3): 127-134. - doi: 10.1016/j.catena.2010.08.001

Warkentin BP, Maeda T (1980). Physical and mechanical characteristics of Andisols. In: "Soils with variable charge" (Theng BKG ed). Offset Publications, Palmerston North, New Zealand, pp. 281-352.

Woignier T, Primera J, Duffours L, Dieudonne P,
Raada A (2008). Preservation of the allophanic soils structure by supercritical drying. Microporous and Mesoporous Materials 109 (1-3): 370-375. - doi: 10.1016/j.micromeso.2007.05.019 Woods SW, Balfour VN (2008). The effect of ash on runoff and erosion after a severe forest wildfire, Montana, USA. International Journal of Wildland Fire 17 (5): 535-548. - doi: 10.1071/ wfo7040

Zobeck TM (1991). Soil properties affecting wind erosion. Journal of Soil and Water Conservation 46 (2): 112-118. [online] URL: http://www.jswc online.org/content/46/2/112.short 